\title{
Calcinaksite, $\mathrm{KNaCa}\left(\mathrm{Si}_{4} \mathrm{O}_{10}\right) \mathrm{H}_{2} \mathrm{O}$, a new mineral from the Eifel volcanic area, Germany
}

\author{
Nikita V. Chukanov ${ }^{1}$ - Sergey M. Aksenov ${ }^{2}$ - Ramiza K. Rastsvetaeva ${ }^{2}$ - Günter Blass ${ }^{3}$. \\ Dmitry A. Varlamov ${ }^{4} \cdot$ Igor V. Pekov $^{5} \cdot$ Dmitry I. Belakovskiy $^{6} \cdot$ Vladislav V. Gurzhiy $^{7}$
}

Received: 29 August 2014 / Accepted: 18 March 2015 /Published online: 29 March 2015

(C) Springer-Verlag Wien 2015

\begin{abstract}
The new mineral calcinaksite, ideally $\mathrm{KNaCa}\left(\mathrm{Si}_{4} \mathrm{O}_{10}\right) \cdot \mathrm{H}_{2} \mathrm{O}$, the first hydrous and Ca-dominant member of the litidionite group, is found in a xenolith of metamorphosed carbonate-rich rock from the southern lava flow of the Bellerberg volcano, Eastern Eifel region, Rheinland-Pfalz, Germany. It is associated with wollastonite, gehlenite, brownmillerite, $\mathrm{Ca}_{2} \mathrm{SiO}_{4}$ (larnite or calcio-olivine), quartz, aragonite, calcite, jennite, tobermorite and ettringite. Calcinaksite occurs as clusters of colourless to light-grey subhedral prismatic crystals. The mineral is brittle, with Mohs' hardness of 5; $\mathrm{D}_{\text {meas }}$ is $2.62(2) \mathrm{g} / \mathrm{cm}^{3}$ and $\mathrm{D}_{\text {calc }}$ is $2.623 \mathrm{~g} / \mathrm{cm}^{3}$. The IR spectrum shows the presence of $\mathrm{H}_{2} \mathrm{O}$ molecules forming three different $\mathrm{H}$-bonds. Calcinaksite is optically biaxial (+), $\alpha=1.542(2), \beta=1.550(2), \gamma=1.565(3)$,
\end{abstract}

Editorial handling: L. Nasdala

Nikita V. Chukanov

chukanov@icp.ac.ru

1 Institute of Problems of Chemical Physics, Russian Academy of Sciences, Chernogolovka, Moscow Region 142432, Russia

2 Institute of Crystallography, Russian Academy of Sciences, Leninsky Prospekt 59, Moscow, Russia 117333

3 Merzbachstrasse 6, 52249 Eschweiler, Germany

4 Institute of Experimental Mineralogy, Russian Academy of Sciences, Chernogolovka, Moscow Region 142432, Russia

5 Faculty of Geology, Moscow State University, Vorobievy Gory, 119991 Moscow, Russia

6 Fersman Mineralogical Museum of the Russian Academy of Sciences, Leninsky Prospekt 18-2, Moscow 119071, Russia

7 Faculty of Geology, St Petersburg State University, University Embankment 7/9, St Petersburg 199034, Russia
$2 V_{\text {meas }}=75(10)$. The chemical composition (electron-microprobe data, $\mathrm{H}_{2} \mathrm{O}$ determined by the Alimarin method, wt $\%$ ) is: $\mathrm{Na}_{2} \mathrm{O} 6.69, \mathrm{~K}_{2} \mathrm{O}$ 12.01, $\mathrm{CaO} 15.04, \mathrm{FeO} 0.59, \mathrm{SiO}_{2} 61.46$, $\mathrm{H}_{2} \mathrm{O}$ 4.9, total 100.69. The empirical formula is $\mathrm{H}_{2.11}$ $\mathrm{K}_{0.99} \mathrm{Na}_{0.84} \mathrm{Ca}_{1.04} \mathrm{Fe}_{0.03} \mathrm{Si}_{3.98} \mathrm{O}_{11}$. The crystal structure was solved and refined to $R_{1}=0.053, w R_{2}=0.075$ based upon 3057 reflections having $I>3 \sigma(I)$. Calcinaksite is triclinic, space group $P \overline{1}, a=7.021(2), b=8.250(3), c=10.145(2) \AA$. $\alpha=102.23(2)^{\circ}, \beta=100.34(2)^{\circ}, \gamma=115.09(3)^{\circ}, V=495.4(3)$ $\AA^{3}, Z=2$. The strongest reflections of the X-ray powder pattern $[d, \AA(I, \%)(h k l)]$ are: $3.431(70)(-121,-211$, $-210,012,0-22), 3.300$ (67) (-031), 3.173 (95) (-103, $-201,-220,003,111), 3.060$ (100) $(-212,2-11,-221$, $200,-1-13,021,-202), 2.851$ (83) (0-23, -122, 1-13, $1-31), 2.664$ (62) (1-23, -222, 201).

\section{Introduction}

The Laacher See area (Eifel Mountains, Germany) is the type locality for more than 20 mineral species, most of which are the result of the interaction of an alkaline magma with xenoliths of different rocks. The processes of mineral formation occurred here quite recently: last eruption of the residual phonolite magma took place $13 \mathrm{Ka}$ ago (Litt et al. 2001; Schmitt et al. 2010). This paper describes the new mineral species from the Laacher See area, calcinaksite $\mathrm{KNaCa}\left(\mathrm{Si}_{4} \mathrm{O}_{10}\right)$. $\mathrm{H}_{2} \mathrm{O}$, which represents the first hydrous and Ca-dominant member of the litidionite group.

Calcinaksite is named for the chemical composition and by analogy to the related minerals manaksite, $\mathrm{KNaMn}\left(\mathrm{Si}_{4} \mathrm{O}_{10}\right)$, and fenaksite, $\mathrm{KNaFe}\left(\mathrm{Si}_{4} \mathrm{O}_{10}\right)$. The mineral and its name have been approved by the IMA Commission on New Minerals, Nomenclature and Classification (IMA no. 2013-081). The 
type material is deposited in the systematic collection of the Fersman Mineralogical Museum of the Russian Academy of Sciences, Moscow, Russia, with catalogue number 94143.

\section{Occurrence, general appearance and physical properties}

Calcinaksite is a product of contact metamorphism (metasomatism) of a xenolith of a calcic carbonate rock (about $15 \times 20 \times 20 \mathrm{~cm}$ in size) hosted in alkaline basalt. A more precise description of initial carbonate rock could not be made because its relics are not preserved. Fragments of this xenolith were collected in 2003 in the southern lava flow of the Bellerberg volcano, between Mayen and Kottenheim towns, Laacher See area, Eastern Eifel region, Rhineland-Palatinate (Rheinland-Pfalz), Germany. Minerals that crystallized before calcinaksite are wollastonite, gehlenite, as well as minor brownmillerite, $\mathrm{Ca}_{2} \mathrm{SiO}_{4}$ (grains up to $5 \mu \mathrm{m}$, presumably larnite or calcio-olivine) and quartz. Wollastonite is the earliest mineral in this association. Minerals that crystallized after calcinaksite (partly in small cavities, cracks and interstices between calcinaksite crystals) include aragonite, calcite, calcium hydrosilicates (jennite and tobermorite-group minerals), ettringite and an amorphous hydrous vitreous phase of composition corresponding to the approximate formula (K,Na, $\mathrm{Ca})_{2}(\mathrm{Si}, \mathrm{Al}, \mathrm{Fe})_{12} \mathrm{O}_{24} \cdot n \mathrm{H}_{2} \mathrm{O}$. Non-identified $\mathrm{Ca}, \mathrm{Zr}$-silicates are also present as accessory phases in aggregates of early minerals (wollastonite, gehlenite and brownmillerite). In particular, the stoichiometry $\mathrm{Ca}:(\mathrm{Zr}+\mathrm{Fe}+\mathrm{Ti}): \mathrm{Si} \approx 3: 2: 2$ determined for some isometric grains can correspond to a hydrogarnet related to kimzeyite.

Calcinaksite forms clusters of colourless to light-grey subhedral prismatic crystals, elongate along $a$ and up to $1 \mathrm{~cm}$ long. They are embedded in aggregates of wollastonite, gehlenite and other unidentified calcium silicates (Figs. 1, 2, and 3). The new mineral is brittle, with Mohs' hardness of 5 .

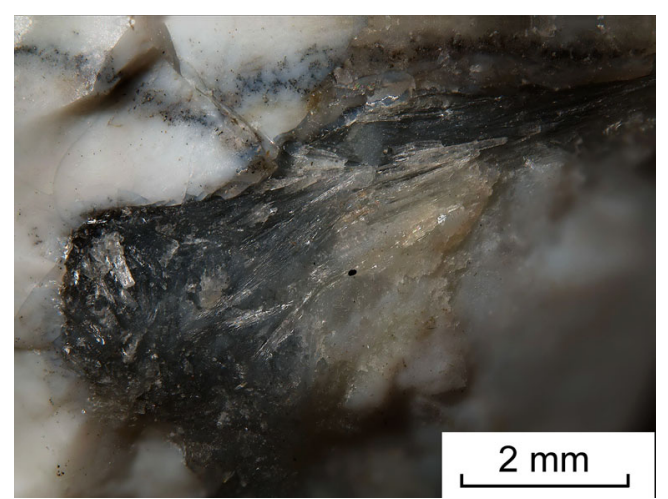

Fig. 1 Cluster of calcinaksite crystals in a fine-grained aggregate of calcium hydrosilicates. Photo: Fred Kruijen
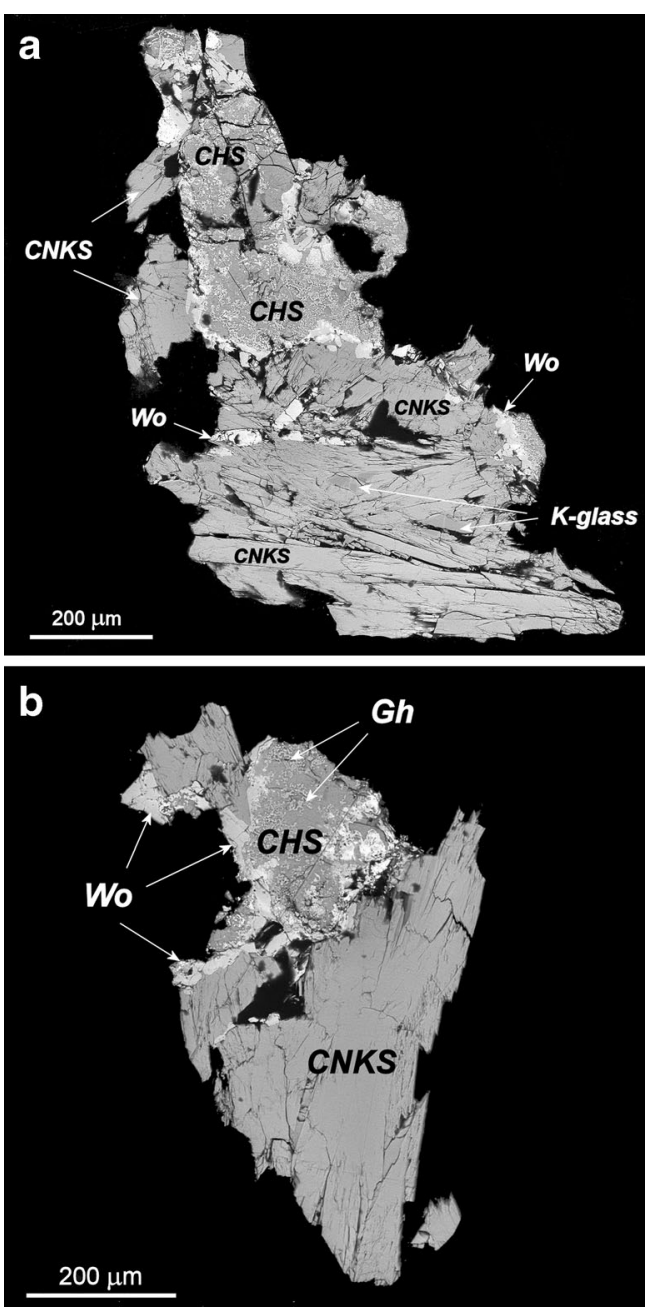

Fig. 2 Calcinaksite (CNKS) aggregates in association with wollastonite (Wo), gehlenite (Gh) and calcium hydrosilicates (CHS). Polished sections. BSE images

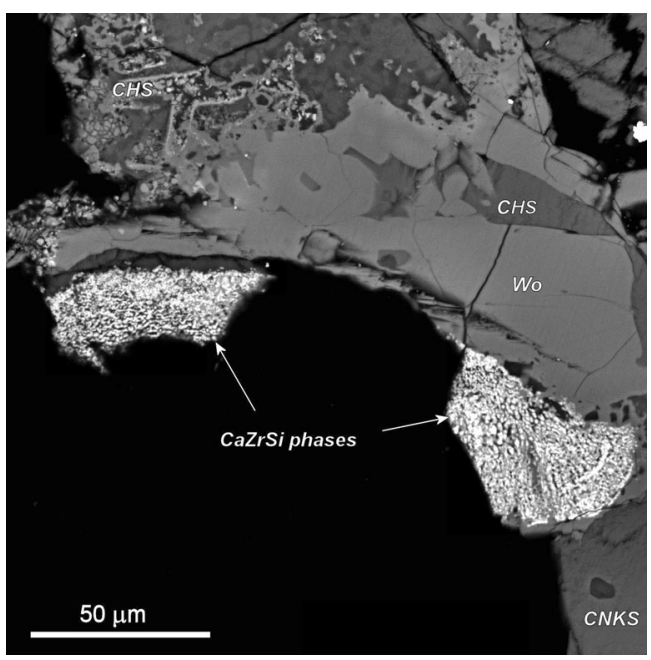

Fig. 3 Aggregates of CaZrSi-minerals (white - kimzeyite-like phase, grey - unidentified phases) with calcinaksite, wollastonite and calcium hydrosilicates. Polished section. BSE image 
Two directions of cleavage are observed: perfect on $\{001\}$ and less perfect on $\{010\}$. Density measured by flotation in heavy liquids (mixtures of bromoform with acetone) is 2.62(2) $\mathrm{g} / \mathrm{cm}^{3}$. Density calculated from the empirical formula is $2.623 \mathrm{~g} / \mathrm{cm}^{3}$.

Calcinaksite is non-fluorescent in both UV and cathode rays.

The new mineral is optically biaxial (+), $\alpha=1.542(2), \beta=$ $1.550(2), \gamma=1.565(3), 2 V_{\text {meas }}=75(10)^{\circ}, 2 V_{\text {calc }}=73^{\circ}$. Dispersion of optical axes is medium, $r<v$. The orientation is: $Y^{\wedge} a=42^{\circ}, Z^{\wedge} a \approx 90^{\circ}$. The plane of perfect cleavage coincides or is almost coplanar with the $X Y$ plane.

\section{Infrared spectroscopy}

Powdered samples of calcinaksite, fenaksite and manaksite were mixed with $\mathrm{KBr}$, pelletized, and analyzed using an ALPHA FTIR spectrometer (Bruker Optics) at the resolution of $4 \mathrm{~cm}^{-1}$ (average of 16 scans). An IR spectrum of an analogous pellet of pure $\mathrm{KBr}$ was used as a reference.

The IR spectrum of calcinaksite is given in Fig. 4. Wavenumbers of absorption bands $\left(\mathrm{cm}^{-1}, \mathrm{~s}-\right.$ strong band, $\mathrm{w}$ - weak band, sh - shoulder) and their assignments are: 3540 , $3340 \mathrm{w}, 3170 \mathrm{w}\left(\mathrm{O}-\mathrm{H}-\right.$ stretching vibrations of $\mathrm{H}_{2} \mathrm{O}$ molecules), 1654w (bending vibrations of $\mathrm{H}_{2} \mathrm{O}$ molecules), 1122, 1075sh, 1055sh, 1041s, 1013, $971 \mathrm{~s}$ (Si-O stretching vibrations), $775 \mathrm{w}, 679,624,597,523$ (bending vibrations of the tubular silicate radical $\left.\mathrm{Si}_{4} \mathrm{O}_{10}\right), 480 \mathrm{sh}, 456$, 421 s, 395w (lattice modes involving $\mathrm{Si}-\mathrm{O}-\mathrm{Si}$ bending and $\mathrm{Ca}-\mathrm{O}$ stretching vibrations).

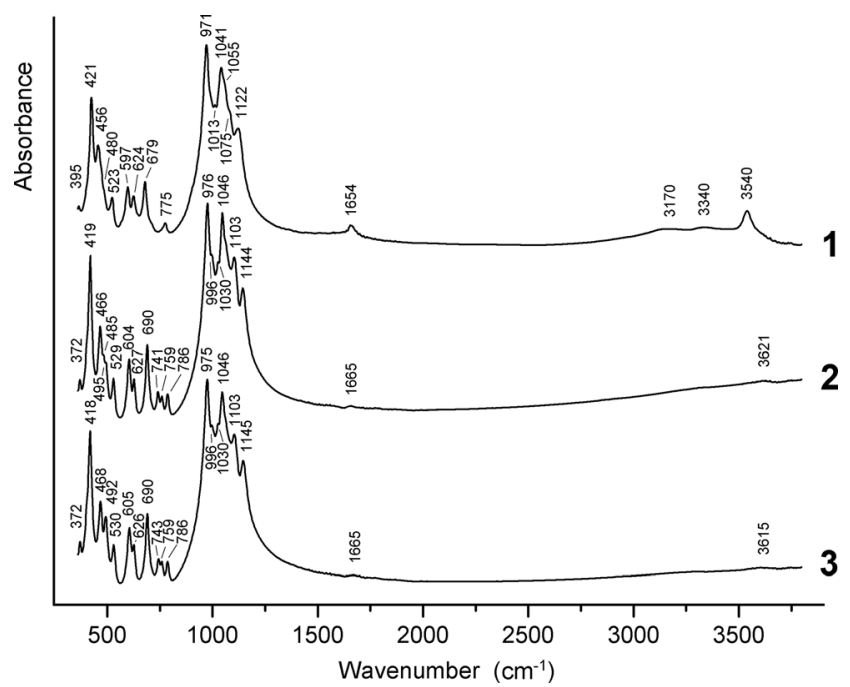

Fig. 4 IR spectra of calcinaksite (1), manaksite from the Palitra pegmatite, Mount Kedykverpakhk, Lovozero massif, Kola peninsula, Russia (2), and fenaksite from Mount Rasvumchorr, Khibiny massif, Kola peninsula (3). The spectra are shown with vertical offset
The IR spectrum of calcinaksite is somewhat similar to those of the structurally related minerals manaksite and fenaksite (Fig. 4). The main differences are observed in the ranges $1500-3700$ and $360-550 \mathrm{~cm}^{-1}$ corresponding to vibrations of $\mathrm{H}_{2} \mathrm{O}$ molecules and the modes involving stretching vibrations of $\mathrm{Ca}$-, $\mathrm{Mn}$ - or Fe-centred polyhedra. Manaksite and fenaksite are considered as anhydrous minerals, but very weak bands for $\mathrm{H}_{2} \mathrm{O}$ molecules are present in their spectra indicating the presence of trace amounts of water. Bands of $\mathrm{BO}_{3}{ }^{3-}$ and $\mathrm{CO}_{3}{ }^{2-}$ groups are absent in the IR spectrum of calcinaksite.

The IR spectrum of calcinaksite is considered as a good diagnostic tool for the mineral. Indeed, among IR spectra of about 2000 mineral species given in the book (Chukanov 2014), only spectra of manaksite and fenaksite have some similarity with that of calcinaksite, but as one can see from Fig. 4, calcinaksite spectrum has a number of distinct specific features. One of them is the presence of $\mathrm{H}_{2} \mathrm{O}$ bands. Fenaksite and manaksite do not contain water because of specific features of their crystal structures. In addition, there are distinct differences between IR spectra of calcinaksite and its $\mathrm{Mn}$ - and Fe-dominant counterparts in the range from 360 to $1200 \mathrm{~cm}^{-1}$.

\section{Chemical composition}

Chemical analyses were carried out as follows. The energydispersive spectroscopic (EDS) electron microprobe analyses, including imaging in scattering electrons (SE) and backscattering electrons (BSE) were carried out with two analytical suites, (1) a digital scanning electron microscope Tescan VEGA-II XMU with energy-dispersive spectrometer INCA Energy 450 and (2) a digital scanning electron microscope CamScan MV2300 (VEGA TS 5130MM) with EDS INCA Energy 350. In both cases data reduction was carried out by means of an INCA Energy 300 software package. The

Table 1 Chemical composition of calcinaksite as determined by SEM energy-dispersive X-ray analysis (average of 18 spot analyses)

\begin{tabular}{lclll}
\hline Constituent & $\mathrm{Wt} \%$ & Range, wt $\%$ & $\begin{array}{l}\text { Standard } \\
\text { deviation, wt } \%\end{array}$ & $\begin{array}{l}\text { Calibrant } \\
\text { material }\end{array}$ \\
\hline $\mathrm{Na}_{2} \mathrm{O}$ & 6.69 & $6.22-7.31$ & 0.26 & Albite \\
$\mathrm{K}_{2} \mathrm{O}$ & 12.01 & $11.21-12.64$ & 0.42 & Microcline \\
$\mathrm{CaO}$ & 15.04 & $14.15-15.66$ & 0.47 & Wollastonite \\
$\mathrm{FeO}$ & 0.59 & b.d.1.-1.11 & 0.31 & $\mathrm{Fe}$ \\
$\mathrm{SiO}_{2}$ & 61.46 & $60.83-62.08$ & 0.45 & $\mathrm{SiO}_{2}$ \\
$\mathrm{H}_{2} \mathrm{O}$ & $4.9(2)^{*}$ & & & \\
$\mathrm{Total}^{100.69}$ & & & \\
\hline
\end{tabular}

*Average of two analyses by the Alimarin method, which gave 4.72 and 5.05 wt. $\% \mathrm{H}_{2} \mathrm{O}$ 
Table 2 Powder X-ray diffraction data for calcinaksite

\begin{tabular}{|c|c|c|c|c|}
\hline$I_{\text {meas }}$ & $d_{\text {meas }}, \AA$ & $I_{\text {calc }} *$ & $d_{\text {calc }} * *$ & $h k l$ \\
\hline 4 & 9.43 & 5 & 9.445 & 001 \\
\hline 36 & 7.07 & 45 & 7.071 & 010 \\
\hline 5 & 6.36 & 3 & 6.348 & -110 \\
\hline 22 & 6.00 & 3,8 & $6.057,5.994$ & $100,-101$ \\
\hline 12 & 5.33 & 15 & 5.340 & -111 \\
\hline 37 & 5.19 & 24 & 5.200 & $1-11$ \\
\hline 9 & 4.94 & 16 & 4.945 & 011 \\
\hline 28 & 4.72 & 31 & 4.722 & 002 \\
\hline 8 & 4.47 & 5,2 & $4.513,4.436$ & $101,-102$ \\
\hline 13 & 3.940 & 19 & 3.926 & $1-21$ \\
\hline 17 & 3.737 & 12,1 & $3.738,3.730$ & $1-12,0-21$ \\
\hline 23 & 3.537 & 52 & 3.535 & 020 \\
\hline 70 & 3.431 & $7,5,15,27,60$ & $3.485,3.455,3.447,3.446,3.407$ & $-121,-211,-210,012,0-22$ \\
\hline 67 & 3.300 & 85 & 3.299 & $0-13$ \\
\hline 95 & 3.173 & $24,34,49,11,26$ & $3.223,3.179,3.174,3.148,3.143$ & $-103,-201,-220,003,111$ \\
\hline 100 & 3.060 & $100,60,18,41,26$ & $3.074,3.058,3.035,3.028,3.020$ & $-212,2-11,-221,200,-1-13$ \\
\hline 83 & 2.851 & 54,72 & $2.853,2.832$ & $0-23,-122$ \\
\hline 62 & 2.664 & $23,31,53$ & $2.701,2.670,2.658$ & $1-23,-222,201$ \\
\hline 10 & 2.587 & $4,16,9$ & $2.600,2.582,2.580$ & $2-22,013,-213$ \\
\hline 44 & 2.534 & $15,6,35,14$ & $2.547,2.545,2.538,2.525$ & $-2-11,-230,112,-2-12$ \\
\hline 52 & 2.493 & $7,4,76$ & $2.499,2.495,2.483$ & $103,0-14,0-31$ \\
\hline 7 & 2.359 & 11 & 2.361 & 004 \\
\hline 21 & 2.275 & $7,14,7$ & $2.274,2.271,2.268$ & $121,0-33,-223$ \\
\hline 12 & 2.176 & 12 & 2.174 & $-1-24$ \\
\hline 14 & 2.153 & 8 & 2.151 & 211 \\
\hline 9 & 2.075 & 10,2 & $2.076,2.075$ & $2-33,-313$ \\
\hline 16 & 2.037 & $8,7,7$ & $2.041,2.038,2.031$ & $-1-32,1-41,-2-22$ \\
\hline 23 & 1.971 & 25 & 1.970 & $-2-23$ \\
\hline 27 & 1.890 & $15,12,23$ & $1.896,1.894,1.889$ & $-241,220,005$ \\
\hline 10 & 1.868 & 21,5 & $1.869,1.865$ & $2-24,0-42$ \\
\hline 4 & 1.835 & 4,10 & $1.838,1.835$ & $-340,-304$ \\
\hline 2 & 1.813 & 3 & 1.817 & $2-34$ \\
\hline 13 & 1.786 & $4,1,8$ & $1.796,1.784,1.782$ & $2-14,-341,0-35$ \\
\hline 45 & 1.749 & $63,2,2,4$ & $1.755,1.753,1.748,1.745$ & $-421,131,3-42,1-32$ \\
\hline 2 & 1.703 & 5,5 & $1.703,1.701$ & $0-44,-412$ \\
\hline 9 & 1.677 & $2,3,2,3$ & $1.681,1.680,1.676,1.675$ & $302,-342,-2-25,-1-35$ \\
\hline 10 & 1.652 & $5,1,5$ & $1.653,1.652,1.649$ & $-305,-410,213$ \\
\hline 5 & 1.611 & $1,3,2,3,1,3$ & $\begin{array}{l}1.613,1.612,1.612,1.612 \\
1.611,1.609\end{array}$ & $\begin{array}{l}1-52,-2-31,-250,-206,311 \\
\quad-125\end{array}$ \\
\hline 13 & 1.571 & $4,4,7,6,1,2$ & $\begin{array}{l}1.574,1.573,1.572,1.572 \\
\quad 1.571,1.568\end{array}$ & $\begin{array}{l}006,2-53,-441,-401,-3-15 \\
\quad 0-45\end{array}$ \\
\hline 5 & 1.553 & 4,3 & $1.554,1.554$ & $3-34,-414$ \\
\hline 14 & 1.513 & $15,1,9$ & $1.514,1.513,1.510$ & $-351,140,-2-26$ \\
\hline 10 & 1.478 & $13,5,1$ & $1.479,1.474,1.474$ & $025,320,3-53$ \\
\hline 13 & 1.436 & $1,4,16,1,7,11$ & $\begin{array}{l}1.438,1.435,1.434,1.434 \\
\quad 1.433,1.433\end{array}$ & $\begin{array}{l}-3-25,0-54,-4-12,-352 \\
\quad-3-16,-450\end{array}$ \\
\hline 7 & 1.426 & $1,2,15$ & $1.426,1.425,1.423$ & $-1-27,1-46,0-27$ \\
\hline 12 & 1.378 & $2,8,3,9,7$ & $1.380,1.380,1.379,1.375,1.374$ & $\begin{array}{l}-530,-2-36,0-37,2-55 \\
\quad-2-43\end{array}$ \\
\hline 5 & 1.341 & 5,7 & $1.341,1.340$ & $-3-26,2-16$ \\
\hline
\end{tabular}


Table 2 (continued)

\begin{tabular}{lllll}
\hline$I_{\text {meas }}$ & $d_{\text {meas }}, \AA$ & $I_{\text {calc }}{ }^{*}$ & $d_{\text {calc }}{ }^{* *}$ & $h k l$ \\
\hline 2 & 1.311 & 1 & 1.312 & -524 \\
2 & 1.299 & 1,2 & $1.301,1.297$ & $-3-17,-514$ \\
4 & 1.279 & $7,7,1,4,2$ & $1.282,1.280,1.279,1.278,1.277$ & $4-24,-543,-4-23,-160,4-61$ \\
7 & 1.270 & $2,6,4$ & $1.272,1.270,1.269$ & $5-32,-550,224$ \\
5 & 1.240 & $5,2,1$ & $1.242,1.241,1.241$ & $-525,0-62,2-37$ \\
2 & 1.229 & $1,4,1$ & $1.232,1.232,1.226$ & $-362,3-46,0-38$ \\
3 & 1.210 & 3 & 1.211 & 500 \\
2 & 1.187 & 2,2 & $1.188,1.187$ & $-218,0-65$ \\
\hline
\end{tabular}

*For the calculated pattern, only reflections with intensities $\geq 1$ are given

**Calculated for unit cell parameters obtained from single-crystal data

analyses were carried out at an accelerating voltage of $20 \mathrm{kV}$. The beam current measured on a reference sample of cobalt was $510-520 \mathrm{pA}$, and on the studied polished samples ranged from 150 to $400 \mathrm{pA}$ (depending on a micro-relief, structure and composition of samples). The size of the electronic beam varied from 157 to $180 \mathrm{~nm}$ in the analytical mode and up to $60 \mathrm{~nm}$ in the scanning mode. The excitation zone reached 4 $5 \mu \mathrm{m}$. The sample-to-detector distance was $25 \mathrm{~mm}$. BSE imaging was carried out with magnifications from 10 to $2500 \mathrm{x}$.

$\mathrm{H}_{2} \mathrm{O}$ was determined by the Alimarin method (Penfield method modified for small samples: selective sorption of $\mathrm{H}_{2} \mathrm{O}$ on $\mathrm{Mg}\left(\mathrm{ClO}_{4}\right)_{2}$ from gaseous products obtained by heating of the mineral at $1100{ }^{\circ} \mathrm{C}$ in an oxygen stream at $1 \mathrm{~atm}) . \mathrm{CO}_{2}$ was not analysed because of the absence of absorption bands corresponding to vibrations of $\mathrm{C}-\mathrm{O}$ bonds in the IR spectrum. Analytical data (average values for analyses from both above-discussed instruments) are given in Table 1 . The contents of other elements with atomic numbers $>8$ are below their detection limits.

The empirical formula based on 11 oxygen atoms is $\mathrm{H}_{2.11}$ $\mathrm{K}_{0.99} \mathrm{Na}_{0.84} \mathrm{Ca}_{1.04} \mathrm{Fe}_{0.03} \mathrm{Si}_{3.98} \mathrm{O}_{11}$. Calcinaksite is quite stable under electronic beam. Consequently, lowered content of $\mathrm{Na}$ could be partly explained by the presence of $\mathrm{Ca}$ and vacancies in the $\mathrm{Na}$ site, according with the following cation grouping: $\mathrm{K}_{0.99}\left(\mathrm{Na}_{0.84} \mathrm{Ca}_{0.07} \square_{0.09}\right)\left(\mathrm{Ca}_{0.97} \mathrm{Fe}_{0.03}\right) \mathrm{Si}_{3.98} \mathrm{O}_{11} \mathrm{H}_{2.11}$. The simplified formula is $\mathrm{KNaCa}\left(\mathrm{Si}_{4} \mathrm{O}_{10}\right) \cdot \mathrm{H}_{2} \mathrm{O}$, which requires $\mathrm{Na}_{2} \mathrm{O}$ 7.89, $\mathrm{K}_{2} \mathrm{O} 12.00, \mathrm{CaO} 14.29, \mathrm{SiO}_{2} 61.23, \mathrm{H}_{2} \mathrm{O} 4.59$, total 100.00 wt. $\%$.

The Gladstone-Dale compatibility index is: $1-\left(\mathrm{K}_{\mathrm{p}} / \mathrm{K}_{\mathrm{c}}\right)=$ 0.007 ("superior"). Calcinaksite is insoluble in dilute hydrochloric acid.

\section{X-ray diffraction data and crystal structure}

Powder X-ray diffraction data for calcinaksite (Table 2) were obtained in the X-ray Diffraction Centre of St. Petersburg State University using the Gandolfi method by means of Agilent Technologies SuperNova single-crystal diffractometer equipped with the source of monochromatic $\mathrm{CuK} \alpha$ radiation $(50 \mathrm{kV}, 0.8 \mathrm{~mA})$ and with an Atlas CCD area-detector in the $2 \Theta$ range from 6 to $86^{\circ}$. A sample-to-detector distance of $55 \mathrm{~mm}$ and pure $\omega$ scans were used. Unit-cell parameters and intensities were obtained using the data reduction package within CrysAlisPro program complex (Agilent Technologies, Version 1.171.36.20). For the refinement of unit-cell parameters we used all reflections with $d<3.5 \AA$ and, if it was possible, with $h \neq 0, k \neq 0$ or $l \neq 0$. In case of multiple reflections, we selected the most intense one for calculations. The unit cell dimensions refined from the powder data are: $a=7.02(2), b=$ 8.26(2), $c=10.15(3) \AA, \alpha=102.38(7)^{\circ}, \beta=100.29(7)^{\circ}, \gamma=$ $114.97(7)^{\circ}, V=496(1) \AA^{3}$.

Table 3 Atom coordinates and equivalent atom displacement parameters for calcinaksite

\begin{tabular}{lllll}
\hline Atom & $x / a$ & $y / b$ & $z / c$ & $U_{\text {eq }} \AA^{2}$ \\
\hline $\mathrm{Ca}$ & $0.2573(1)$ & $0.7357(1)$ & $0.0833(1)$ & $0.0171(3)$ \\
$\mathrm{K}$ & $-0.1471(2)$ & $0.2015(1)$ & $0.4914(1)$ & $0.0263(3)$ \\
$\mathrm{Na}$ & $0.7505(3)$ & $0.6953(3)$ & $0.0833(2)$ & $0.0255(7)$ \\
$\mathrm{Si} 1$ & $0.1113(2)$ & $0.3996(1)$ & $0.2468(1)$ & $0.0138(3)$ \\
$\mathrm{Si} 2$ & $0.5777(2)$ & $0.7107(1)$ & $0.3645(1)$ & $0.0144(3)$ \\
$\mathrm{Si3}$ & $0.2507(2)$ & $1.1014(1)$ & $0.3073(1)$ & $0.0141(3)$ \\
$\mathrm{Si} 4$ & $0.3375(2)$ & $0.6179(1)$ & $-0.2471(1)$ & $0.0150(3)$ \\
O1 & $-0.0968(4)$ & $0.3939(4)$ & $0.3013(3)$ & $0.018(1)$ \\
O2 & $0.1243(5)$ & $0.8828(4)$ & $0.2283(3)$ & $0.021(1)$ \\
O3 & $0.3028(5)$ & $0.4210(4)$ & $-0.3485(3)$ & $0.022(1)$ \\
O4 & $0.1143(5)$ & $1.2081(4)$ & $0.2586(3)$ & $0.024(1)$ \\
O5 & $0.2893(5)$ & $1.1384(4)$ & $0.4772(3)$ & $0.022(1)$ \\
O6 & $0.5844(5)$ & $0.8104(4)$ & $0.2484(3)$ & $0.022(1)$ \\
O7 & $0.3270(5)$ & $0.5800(4)$ & $0.3673(3)$ & $0.022(1)$ \\
O8 & $0.4969(5)$ & $1.2081(4)$ & $0.2892(3)$ & $0.021(1)$ \\
O9 & $0.4137(5)$ & $0.6427(4)$ & $-0.0846(3)$ & $0.021(1)$ \\
O10 & $0.0952(5)$ & $0.4206(4)$ & $0.0948(3)$ & $0.019(1)$ \\
Ow ${ }^{*}$ & $0.2839(8)$ & $0.9805(5)$ & $-0.0292(4)$ & $0.053(2)$ \\
\hline
\end{tabular}

$* \mathrm{O}$ atom of the $\mathrm{H}_{2} \mathrm{O}$ molecule 


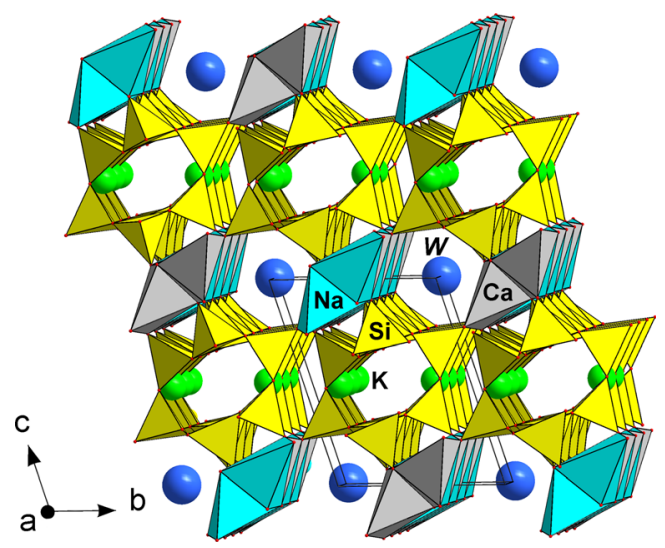

Fig. 5 The crystal structure of calcinaksite: general view

The single-crystal X-ray diffraction data for calcinaksite have been collected in a full sphere of the reciprocal space using an Xcalibur Oxford Diffraction CCD-diffractometer. The following triclinic unit-cell parameters have been obtained: $a=7.021(2), b=8.250(3), c=10.145(2) \AA, \alpha=102.23(2)$, $\beta=100.34(2), \gamma=115.09(3)^{\circ}$, space group $P \overline{1}$ (no. 2). The crystal structure of calcinaksite has been refined up to $R=$ $5.3 \%$ and $w R=7.5 \%$ in anisotropic approximation using 3057 reflections with $I>3 \sigma(I)$ (Aksenov et al. 2014; Table 3).

The basic structural unit of all these minerals is an infinite tube $\left[\mathrm{Si}_{8} \mathrm{O}_{20}\right]^{8-}{ }_{\alpha}$ running along [100] (Fig. 5). The lateral surface of the tube is formed by four- and eight-membered tetrahedral rings.

The tubes are joined together by edge sharing $\mathrm{CaO}_{5}\left(\mathrm{H}_{2} \mathrm{O}\right)$ and $\mathrm{NaO}_{5}$ polyhedra. The $\mathrm{CaO}_{5}\left(\mathrm{H}_{2} \mathrm{O}\right)$ polyhedron is a square bipyramid whose base is formed by four oxygen atoms at distances ranging from 2.282 to $2.399 \AA$. The oxygen atom located in a distance of $2.395 \AA$ from calcium is the apical vertex. Another apical vertex is occupied with an $\mathrm{H}_{2} \mathrm{O}$ molecule located at $2.482 \AA$ from Ca (Fig. 6).

The $\mathrm{NaO}_{5}$ polyhedron is a regular square-based pyramid with four longer bonds at 2.457-2.530 $\AA$ and a shorter apical bond $2.375 \AA$ long.

The pairs of $\mathrm{CaO}_{5}\left(\mathrm{H}_{2} \mathrm{O}\right)$ octahedra sharing edges (Fig. 6) alternate with the pairs of Na-centered pyramids to form serrated bands running parallel to [100] (Fig. 5). The K atom was

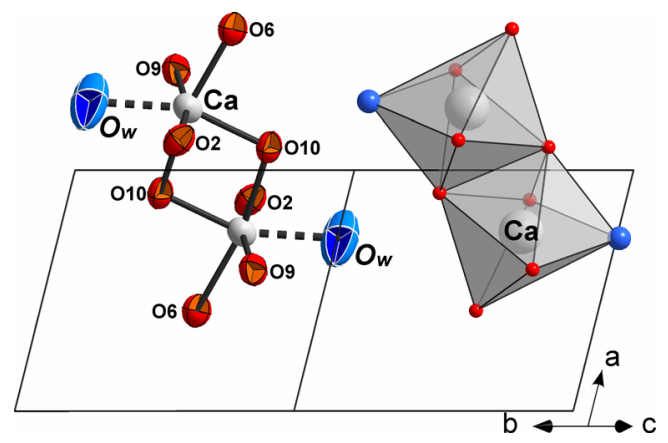

Fig. 6 The pair of $\mathrm{CaO}_{5}\left(\mathrm{H}_{2} \mathrm{O}\right)$ octahedra found within a large cavity of the silicate tube with K-O distances of 2.656-3.234 ̊..

A detailed description of the crystal structure of calcinaksite and its comparison with structures of related minerals and synthetic compounds are given elsewhere (Aksenov et al. 2014).

\section{Discussion}

The principle features that distinguish calcinaksite from other members of the litiodionite group are the presence of $\mathrm{H}_{2} \mathrm{O}$ and the role of $\mathrm{Ca}$ in this mineral. Calcinaksite differs from other litidionite-group minerals, manaksite $\mathrm{KNaMn}^{2+}\left(\mathrm{Si}_{4} \mathrm{O}_{10}\right)$, fenaksite $\mathrm{KNaFe}^{2+}\left(\mathrm{Si}_{4} \mathrm{O}_{10}\right)$ and litidionite $\mathrm{KNaCu}^{2+}\left(\mathrm{Si}_{4} \mathrm{O}_{10}\right)$, also in some features of the crystal structure, in particular, in the coordination of cationic sites (Table 4). Calcinaksite is also structurally related to the synthetic compounds with general formula $\mathrm{Na}_{2} M\left[\mathrm{Si}_{4} \mathrm{O}_{10}\right]$ (where $M=\mathrm{Co}, \mathrm{Ni}, \mathrm{Cu}, \mathrm{Mn}$ ) as well as $\mathrm{KNa} M\left[\mathrm{Si}_{4} \mathrm{O}_{10}\right](M=\mathrm{Cu}, \mathrm{Mn}, \mathrm{Fe})$ (Kornev et al. 1972; Kawamura and Kawahara 1977; Durand et al. 1997; Brandão et al. 2009; Cadoni and Ferraris 2011).

In manaksite, the Mn-centered coordination polyhedron is a distorted trigonal bipyramid with an apical bond relatively longer $(2.30 \AA)$ than equatorial ones $(2.05-2.14 \AA)$. The $\mathrm{NaO}_{5}$ polyhedron is a tetragonal pyramid with an apical bond of $2.83 \AA$ and four bonds ranging from 2.38 to $2.49 \AA$ (Karimova and Burns 2008). In fenaksite, the Fe-centered tetragonal pyramid has $\mathrm{Fe}-\mathrm{O}$ distances ranging from 1.992 to $2.140 \AA$ while the apical oxygen is located at a distance of $2.288 \AA$ from Fe. Sodium atom has the coordination 4+3: besides four bonds with the lengths from 2.394 to 2.502(2) $\AA$, there are three longer bonds with oxygen atoms ranging from 2.828 to $3.031 \AA$ (Rozhdestvenskaya et al. 2004). In litidionite $\mathrm{KNaCu}^{2+}\left(\mathrm{Si}_{4} \mathrm{O}_{10}\right)$ (Pozas et al. 1975), the Cu-centered polyhedron is a fairly regular square pyramid whose base is formed by four oxygen atoms at distances ranging from 1.961 to $1.990 \AA$, and the apex at a distance of $2.549 \AA$ from $\mathrm{Cu}$. Na in litidionite has 7 -fold coordination, with five bond distances of 2.386-2.581 $\AA$ and two at 2.850 and $2.932 \AA$.

Fenaksite and manaksite occur in peralkaline rocks and form solid solution within a wide range of Fe:Mn ratios

Table 4 Coordination of cations in the structures of litidionite-group minerals

\begin{tabular}{llrlll}
\hline Mineral & $M$ & $\mathrm{Na}$ & $\mathrm{K}$ & Reference \\
\hline Manaksite $(M=\mathrm{Mn})$ & $3+2$ & $4+1$ & 9 & Karimova and Burns (2008) \\
Fenaksite $(M=\mathrm{Fe})$ & $4+1$ & $4+3$ & 9 & Rozhdestvenskaya et al. (2004) \\
Litidionite $(M=\mathrm{Cu})$ & $4+1$ & $5+2$ & 8 & Pozas et al. (1975) \\
Calcinaksite $(M=\mathrm{Ca})$ & $5+1$ & 5 & 9 & Aksenov et al. 2014 \\
\hline
\end{tabular}


(Dorfman et al. 1959; Khomyakov et al. 1992; Ageeva 2000). Calcinaksite-bearing mineral association was formed as a result of contact-type metamorphism of a calcic carbonate rock and subsequent low-temperature reactions. Such processes have attracted the attention of researchers for a long time (Gross 1977; Grapes 2011; Bucher and Grapes 2011). One of the reasons for the interest of natural high-temperature metamorphism at the contact of basalt magma with calciterich rocks is its analogy with cement production processes (Taylor 1997). The study of different phases of cement materials is difficult because of their small sizes. Natural metamorphic rocks are often more coarse-grained and consequently more suitable for detailed studies of the mineral composition.

The hydrothermal synthesis and magnetic properties of fenaksite, manaksite and litidionite are described by Brandão et al. (2009). The manaksite-like compound $\mathrm{Na}_{2} \mathrm{MnSi}_{4} \mathrm{O}_{10}$ was also synthesized under hydrothermal conditions (Cadoni and Ferraris 2011). All these compounds either do not contain water, or contain it in trace amounts. By analogy with related synthetic compounds, one can suppose that calcinaksite has hydrothermal origin. Despite calcinaksite crystallized before associated silicate minerals of the low-temperature hydrothermal stage (tobermorite and jennite), it contains water molecules as a species-defining component. Moreover, calcinaksite was formed near the earth's surface, and consequently at low partial pressure of $\mathrm{H}_{2} \mathrm{O}$, unlike related anhydrous synthetic compounds. Based on these facts, we suppose that the incorporation of $\mathrm{H}_{2} \mathrm{O}$ in the structure of calcinaksite is caused by crystal-chemical factors rather than by specific conditions of its formation.

In the calcinaksite structure three kinds of channels are present. Channel I (i.e., the tube $\left[\mathrm{Si}_{8} \mathrm{O}_{20}\right]^{8-}$ ) is empty, channel III running along the $b$ axis is occupied with $\mathrm{K}$, and channel II (delimited by six-membered rings formed by $\mathrm{SiO}_{4}$ tetrahedra and $M$ - or $A$ '-centered polyhedra) extends parallel to the $a$ axis and contains water molecules. In the structures of other litidionite-group minerals and their synthetic analogues channel III is also occupied with $\mathrm{K}$, but channel II is empty. In the

Table 5 Comparative data for calcinaksite and other litidionite-group minerals

\begin{tabular}{|c|c|c|c|c|}
\hline $\begin{array}{l}\text { Mineral } \\
\text { Formula } \\
\text { Crystal system } \\
\text { Space group }\end{array}$ & $\begin{array}{l}\text { Calcinaksite } \\
\mathrm{KNaCa}\left(\mathrm{Si}_{4} \mathrm{O}_{10}\right) \cdot \mathrm{H}_{2} \mathrm{O} \\
\text { Triclinic } \\
P \overline{1}\end{array}$ & $\begin{array}{l}\text { Manaksite } \\
\mathrm{KNaMn}^{2+}\left(\mathrm{Si}_{4} \mathrm{O}_{10}\right) \\
\text { Triclinic } \\
P \overline{1}\end{array}$ & $\begin{array}{l}\text { Fenaksite } \\
\mathrm{KNaFe}^{2+}\left(\mathrm{Si}_{4} \mathrm{O}_{10}\right) \\
\text { Triclinic } \\
P \overline{1}\end{array}$ & $\begin{array}{l}\text { Litidionite } \\
\mathrm{KNaCu}^{2+}\left(\mathrm{Si}_{4} \mathrm{O}_{10}\right) \\
\text { Triclinic } \\
P \overline{1}\end{array}$ \\
\hline$a, \AA$ & $7.021(2)$ & $6.9851(6)$ & $6.9742(3)$ & $6.9704(4)$ \\
\hline$b, \AA$ & $8.250(3)$ & $8.1825(7)$ & $8.1326(3)$ & $8.0111(5)$ \\
\hline$c, \AA$ & $10.145(2)$ & $9.9747(1)$ & $9.9301(4)$ & $9.7896(9)$ \\
\hline$\alpha,{ }^{\circ}$ & $102.23(2)$ & $105.70(1)$ & $105.78(1)$ & $105.56(1)$ \\
\hline$\beta, \circ$ & $100.34(2)$ & $99.51(1)$ & $100.06(1)$ & $99.53(1)$ \\
\hline$\gamma,{ }^{\circ}$ & $115.09(3)$ & $114.58(1)$ & $114.26(1)$ & $114.16(1)$ \\
\hline$V, \AA^{3}$ & $495.4(3)$ & $473.33(9)$ & $467.05(6)$ & $456.32(1)$ \\
\hline \multirow{7}{*}{$\begin{array}{l}\text { Strong lines of the powder } \\
\text { X-ray diffraction pattern: } \\
d, \AA\left(I_{\text {rel }}\right)\end{array}$} & $3.431(70)$ & $6.89(70)$ & $3.55(70)$ & $6.75(35)$ \\
\hline & $3.300(67)$ & $3.45(100)$ & $3.44(70)$ & $3.652(18)$ \\
\hline & $3.173(95)$ & $3.26(90)$ & $3.03(100)$ & $3.372(100)$ \\
\hline & $3.060(100)$ & $3.05(80)$ & $2.88(60)$ & $3.223(75)$ \\
\hline & $2.851(83)$ & $2.880(70)$ & $2.71(60)$ & 2.835 (18) \\
\hline & $2.664(62)$ & $2.715(70)$ & $2.46(70)$ & $2.675(37)$ \\
\hline & $2.493(52)$ & $2.463(70)$ & $1.875(60)$ & $2.409(85)$ \\
\hline \multirow[t]{5}{*}{ Optical data } & Biaxial $(+)$ & Biaxial (-) & Biaxial $(+)$ & Biaxial (-) \\
\hline & $\alpha=1.542$ & $\alpha=1.540$ & $\alpha=1.541$ & $\alpha=1.548$ \\
\hline & $\beta=1.550$ & $\beta=1.551$ & $\beta=1.560$ & $\beta=1.574$ \\
\hline & $\gamma=1.565$ & $\gamma=1.557$ & $\gamma=1.567$ & $\gamma-$ n. d. \\
\hline & $2 V=75^{\circ}$ & $2 V=73^{\circ}$ & $2 V=84^{\circ}$ & $2 V=56^{\circ}$ \\
\hline \multirow[t]{2}{*}{ Density, $\mathrm{g} \mathrm{cm}^{-3}$} & 2.62 (meas.) & 2.73 (meas.) & 2.744 (meas.) & 2.75 (meas.) \\
\hline & 2.623 (calc.) & 2.71 (calc.) & 2.74 (calc.) & 2.85 (calc.) \\
\hline References & This work & $\begin{array}{l}\text { Khomyakov et al. 1992; } \\
\text { Karimova and Burns } \\
\text { 2008; Brandão et al. } 2009\end{array}$ & $\begin{array}{l}\text { Dorfman et al. 1959; } \\
\text { Golovachev et al. 1970; } \\
\text { Chukhrov and } \\
\text { Smolianinova 1981; } \\
\text { Rozhdestvenskaya et al. } \\
\text { 2004; Brandão et al. } 2009\end{array}$ & $\begin{array}{l}\text { Pozas et al. 1975; } \\
\text { Chukhrov and } \\
\text { Smolianinova 1981; } \\
\text { Brandão et al. 2009 }\end{array}$ \\
\hline
\end{tabular}


related mineral agrellite, channel III incorporates $\mathrm{Na}$, and channel II contains F. The presence of water molecules only in calcinaksite structure is related to the dimensions of channel II, which in turn depends on the $M$ cation radius. Note that $\mathrm{Ca}$ is the largest cation among $M$ cations known in litidionitegroup minerals. As a result, the dimensions of the largest cross-section of channel II in calcinaksite $(3.0 \times 3.5 \AA)$ are larger than corresponding dimensions in fenaksite structure $(2.8 \times 2.9 \AA)$. The smallest cross-section of channel II in calcinaksite has the dimensions $2.4 \times 3.0 \AA$. Consequently, the incorporation of $\mathrm{H}_{2} \mathrm{O}$ into calcinaksite on the postcrystallization stage would be impossible. All these facts indicate that calcinaksite was formed during the hightemperature hydrothermal stage.

Natural samples of manaksite and fenaksite contain minor amounts of $\mathrm{Ca}(<1 \mathrm{wt} . \% \mathrm{CaO})$. Trace amounts of $\mathrm{H}_{2} \mathrm{O}$ detected in these minerals by IR spectroscopy can be present as a part of the octahedron $\mathrm{CaO}_{5}\left(\mathrm{H}_{2} \mathrm{O}\right)$ in unit cells with $\mathrm{Ca}$ substituting $\mathrm{Mn}$ and $\mathrm{Fe}$, respectively. Comparative data for calcinaksite and related minerals are given in Table 5.

Acknowledgments We are grateful to Svetlana A. Vozchikova for assistance in the measurement of density of calcinaksite and to Larisa A. Korshunova for the determination of $\mathrm{H}_{2} \mathrm{O}$. We are also grateful to Lutz Nasdala, Andreas Ertl, Johann Raith and an anonymous referee for reviewing the paper. This study was supported by the Russian Foundation for Basic Research (grants nos. 14-05-00190-a and 14-05-31150 mol_a) and grant No MK-4990.2014.5 of the Foundation of the President of the Russian Federation. Technical support by the SPbSU X-Ray Diffraction Resource Center is gratefully acknowledged.

\section{References}

Ageeva OA (2000) New fenaksite-manaksite isomorphous series. Dokl Earth Sci 373A:927-929

Aksenov SM, Rastsvetaeva RK, Chukanov NV, Kolitsch U (2014) Structure of calcinaksite $\mathrm{KNa}\left[\mathrm{Ca}\left(\mathrm{H}_{2} \mathrm{O}\right)\right]\left[\mathrm{Si}_{4} \mathrm{O}_{10}\right]$, the first hydrous member of the litidionite group of silicates with $\left[\mathrm{Si}_{8} \mathrm{O}_{20}\right]^{8-}$ tubes. Acta Cryst B 70:768-775

Brandão P, Rocha J, Reis MS, dos Santos AM, Jin R (2009) Magnetic properties of $\mathrm{KNaMSi}_{4} \mathrm{O}_{10}$ compounds $(\mathrm{M}=\mathrm{Mn}, \mathrm{Fe}, \mathrm{Cu})$. J Solid State Chem 182:253-258
Bucher K, Grapes R (2011) Petrogenesis of metamorphic rocks. Springer Verlag, Heidelberg

Cadoni M, Ferraris G (2011) Synthesis and crystal structure of $\mathrm{Na}_{2} \mathrm{MnSi}_{4} \mathrm{O}_{10}$ : relationship with the manaksite group. Rend Lincei, Sci Fisiche Nat 22:225-234

Chukanov NV (2014) Infrared spectra of mineral species: extended library. Springer Verlag, Dordrecht

Chukhrov FV, Smolianinova NN (eds) (1981) Minerals. Nauka, Moscow, Volume III(3) (in Russian)

Dorfman MD, Rogachev DD, Goroshchenko ZI, Mokretsova AV (1959) Fenaksite - a new mineral. Tr Mineralogicheskogo Muzeya Akademiy Nauk SSSR 9:152-157 (in Russian)

Durand G, Vilminot S, Richard-Plouet M, Derory A, Lambour JP, Drillon $\mathrm{M}$ (1997) Magnetic behavior of $\mathrm{Na}_{2} \mathrm{MSi}_{4} \mathrm{O}_{10}(M=\mathrm{Co}, \mathrm{Ni})$ compounds. J Solid State Chem 131:335-340

Golovachev VP, Drozdov YN, Kuz'min EA, Belov NV (1970) The crystal structure of fenaksite, $\mathrm{NaKFeSi}_{4} \mathrm{O}_{10}$. Dokl Akad Nauk SSSR 194:818-820 (in Russian)

Grapes R (2011) Pyrometamorphism. Springer Verlag, Heidelberg

Gross S (1977) The mineralogy of the Hatrurim formation, Israel. Geological survey of Israel, bulletin no. 70

Karimova O, Burns PC (2008) Silicate tubes in the crystal structure of manaksite. In: Krivovichev S (ed) Minerals as advanced materials I. Springer, Berlin, pp 153-157

Kawamura K, Kawahara A (1977) The crystal structure of synthetic copper sodium silicate: $\mathrm{CuNa}_{2} \mathrm{Si}_{4} \mathrm{O}_{10}$. Acta Cryst B33:1071-1075

Khomyakov AP, Kurova TA, Nechelyustov GN (1992) Manaksite, $\mathrm{NaKMnSi}_{4} \mathrm{O}_{10}$, a new mineral. Zap Vses Mineral O-va 121:112115 (in Russian)

Kornev AN, Maksimov BA, Lider VV, Ilyukhin VV, Belov NV (1972) Crystal structure of $\mathrm{Na}_{2} \mathrm{Cu}\left[\mathrm{Si}_{4} \mathrm{O}_{10}\right]$. Sov Phys Dokl 17:735-737 (in Russian)

Litt T, Brauer A, Goslar T, Merk J, Balaga K, Mueller H, RalskaJasiewiczowa M, Stebich M, Negendank JFW (2001) Correlation and synchronisation of late glacial continental sequences in northern Central Europe based on annually laminated lacustrine sediments. In: Bjorck S, Lowe JJ, Walker MJC (eds): Integration of ice core, marine and terrestrial records of Termination 1 from the North Atlantic region. Quatern Sci Rev. 20:1233-1249

Pozas JMM, Rossi G, Tazzoli V (1975) Re-examination and crystal structure analysis of litidionite. Am Minerol 60:471-474

Rozhdestvenskaya IV, Bannova II, Nikishova LV, Soboleva TV (2004) The crystal structure of fenaksite $\mathrm{K}_{2} \mathrm{Na}_{2} \mathrm{Fe}_{2} \mathrm{Si}_{8} \mathrm{O}_{20}$. Dokl Earth Sci 398:1029-1033

Schmitt AK, Wetzel F, Cooper KM, Zou H, Wörner G (2010) Magmatic longevity of Laacher See volcano (Eifel, Germany) indicated by UTh dating of intrusive carbonatites. J Petrol 51:1053-1085

Taylor HFW (1997) Cement chemistry. Thomas Telford Ltd edition, London 